\title{
20: 1548630-1491568
}

National Cancer Institute

\section{Source}

National Cancer Institute. 20: 1548630-1491568. NCI Thesaurus. Code C45087.

Physical location of SIRPB1_Gene 